\title{
Monoclonal antibodies to the glycoprotein and nucleoprotein of infectious hematopoietic necrosis virus (IHNV) reveal differences among isolates of the virus by fluorescence, neutralization and electrophoresis
}

\author{
Sandra S. Ristow, Jeanene Arnzen de Avila \\ Department of Animal Sciences, Washington State University, Pullman, Washington 99164-6332, USA
}

\begin{abstract}
Monoclonal antibodies were produced to the glycoproteins and nucleoproteins of several isolates of infectious hematopoietic necrosis virus (IHNV). Antibodies were selected for cloning by enzyme-linked immunosorbent assay (ELISA), neutralization tests, indirect fluorescence and by their ability to immunoprecipitate viral proteins. To test the utility of this group of monoclonal antibodies for virus typing, 17 strains of IHNV from different geographical regions, years, and from different fish stocks were analyzed by: immunoprecipitation followed by polyacrylamide gel electrophoresis, indirect fluorescence with 27 monoclonal antibodies, and serum neutralization with 6 monoclonal anti-glycoprotein antibodies. Uising SDS gel electrophoresis, minor variations in nucleoprotein molecular weights were noted among the 17 selected isolates. Serum neutralization of the 17 isolates with 2 of the antiglycoprotein antibodies, $3 \mathrm{GH} 127 \mathrm{~B}$ and $3 \mathrm{GH} 92 \mathrm{~A}$, divided the 17 selected isolates into 2 groups, those which were neutralized with both antibodies, and those which were not. Typing by indirect fluorescence with the antibodies, however, indicated that antigenic variation existed between isolates. Twenty-eight older isolates of IHNV, previously classified into electrophoretic types I to V, and 10 recent isolates were also tested by immunofluorescence for reaction with the monoclonal antibodies.
\end{abstract}

\section{INTRODUCTION}

Infectious hematopoietic necrosis virus (IHNV) is an economically important rhabdovirus which infects salmonid fish (Pilcher \& Fryer 1980, Groberg \& Fryer 1983, Fryer 1985, Wolf 1988). Over the past $40 \mathrm{yr}$ in North America, IHNV has caused millions of dollars in damage to both public and private aquaculture facilities. Not only does IHNV kill juvenile fish, but it also infects yearling fish (LaPatra et al. 1990). Until recently, IHNV appeared confined to North America, Japan (Sano 1976) and China (Luqi \& Zhizhuang 1988). Now, however, IHNV has spread to Europe (Arkush et al. 1989, Hattenberger-Baudouy et al. 1989).

The IHNV virion is composed of 5 proteins: a polymerase (L), coat glycoprotein (G), nucleoprotein $(N), 2$ membrane proteins (M1 and M2) and a negative sense single stranded RNA genome which codes for these proteins plus a non-virion protein (NV) (McAllister \& Wagner 1975, Kurath \& Leong 1985, Kurath et al. 1985)
A number of studies have indicated that serological differences exist among various isolates of IHNV. An early study by McCain et al. (1971) showed that certain isolates of IHNV were neutralized at different rates by polyclonal antiserum. Newer studies based on monoclonal antibodies made to IHNV revealed antigenic variation in the glycoproteins of various isolates by serum neutralization (Winton et al. 1988) and in the nucleoproteins by indirect fluorescence tests (Ristow \& Arnzen 1989).

Electropherotyping IHNV has become a standard method for classifying the virus (Hsu et al. 1986). This method has provided important information concerning the biology of the virus including: (1) that many salmonid species in the same geographical area yield isolates of IHNV possessing polypeptides of identical molecular weight, and (2) that the same electropherotype is exhibited by IHNV isolates from infected parents and their progeny.

The purposes of the present study were: (1) to note variations among selected isolates of IHNV by 3 
methods (fluorescence, neutralization, and electrophoresis) using monoclonal antibodies; (2) to document the indirect fluorescence patterns of the antinucleoprotein and antiglycoprotein monoclonal antibodies using isolates of IHNV which had been previously electropherotyped (Hsu et al. 1986); and (3) to validate the general usefulness of the panel of monoclonal antibodies for distinguishing between isolates of IHNV.

\section{MATERIALS AND METHODS}

Virus. Seventeen selected isolates of IHNV, listed in Table 1, were supplied frozen on dry ice by Jo-Ann Leong and John Rohovec of Oregon State University, Corvallis, OR, USA Isolates which were typed by SDS gel electrophoresis in a previous study (Hsu et al. 1986) were supplied by Jo-Ann Leong and H. Mark Engelking of Oregon State University. Isolates from 1989 and 1990 epizootics were received from Joe Lientz and Colleen Hesson of Dworshak National Fish Hatchery, Ahsahka, ID, USA; Scott LaPatra, Oregon Department of Fish and Game, Corvallis; Warren Groberg, Eastern Oregon State College, LaGrande, OR; Robert Busch, Clear Springs Trout, Buhl, ID; Steve Roberts, Washington Department of Fisheries, Wenatchee, WA, USA; Scott Foote, Coleman National Fish Hatchery, Anderson, CA, USA; Kent Hauck, Idaho Department of Fish and Game, Eagle, ID; and Garth Traxler, Department

Table 1. Isolates of IHNV categorized by geographical location, host and year

\begin{tabular}{|c|c|c|c|}
\hline Isolate & Source & $\operatorname{Host}^{a}$ & Year \\
\hline Cedar River & Washington & SS & 1980 \\
\hline Cedar River & Washington & SS & 1980 \\
\hline Coleman & California & $\mathrm{Ch}$ & 1982 \\
\hline Coleman & California & $\mathrm{Ch}$ & 1979 \\
\hline Cole Rivers & Oregon & $\mathrm{CH}$ & 1989 \\
\hline Dworshak & Idaho & St & 1982 \\
\hline Dworshak & Idaho & St & 1989 \\
\hline Elk River & Oregon & $\mathrm{Ch}$ & 1982 \\
\hline Hagerman 039-82SR & Idaho & $\mathrm{RbT}$ & 1982 \\
\hline Hagerman 039-820SU & Idaho & $\mathrm{RbT}$ & 1982 \\
\hline Little White Salmon & Washington & $\mathrm{Ch}$ & 1987 \\
\hline Metolius & Oregon & $\mathrm{KO}$ & 1988 \\
\hline Rangen Research & Idaho & $\mathrm{RbT}$ & 1983 \\
\hline Round Butte Hatchery & Oregon & $\mathrm{St}$ & 1983 \\
\hline Round Butte Hatchery & Oregon & $\mathrm{St}$ & 1986 \\
\hline Kound Butte Hatchery & Oregon & $\mathrm{St}$ & 1989 \\
\hline Round Butte Hatchery & Oregon & $\mathrm{Ch}$ & 1989 \\
\hline \multicolumn{4}{|c|}{$\begin{array}{l}\text { 'SS = sockeye salmon Oncorhynchus nerka; } \mathrm{Ch}= \\
\text { chinook salmon } \mathrm{O} \text {. tshawytscha; } \mathrm{St}=\text { steelhead', anad- } \\
\text { romous rainbow trout } \mathrm{O} \text {. mykiss; } \mathrm{RbT}=\text { rainbow trout } \mathrm{O} \text {. } \\
\text { mykiss; } \mathrm{KO}=\text { kokannee, lacustrine sockeye salmon } \mathrm{O} \text {. } \\
\text { nerka }\end{array}$} \\
\hline
\end{tabular}

of Fisheries and Oceans, Nanaimo, B.C., Canada. The isolates were not plaque purified before use.

Monoclonal antibodies. Monocional antibodies to the $G$ and $N$ proteins of several strains of IHNV [Hagerman 039-82SR, Coleman 2 (CO2), Feather River (FR), Cedar River (CD) and Dworshak 2 (DW)], were produced by fusion of immunized spleen cells with the P3X63-Ag8.653 BALB/C mouse myeloma using methods described in a previous publication by Ristow \& Arnzen (1989). Hybridoma colonies were selected by enzyme-linked immunosorbent assay (ELISA), indirect fluorescence, neutralization tests and the ability of their supernatants to immunoprecipitate ${ }^{35} \mathrm{~S}$ radiolabeled viral proteins from lysates of infected cultures (Ristow \& Arnzen 1989). Cloning and ascites production were performed as previously described (Ristow \& Arnzeñ 1989). Isotypes of monoclonal antibodies were determined with a commercially available kit (BioRad, Richmond, CA).

Infection and radioactive labeling of cultures. A $75 \mathrm{~cm}^{2}$ flask of CHSE-214 cells (Nims et al. 1970) was infected with a single isolate of IHNV at a multiplicity of 10 . The virus sample was adsorbed to the monolayer for $1 \mathrm{~h}$ at $16^{\circ} \mathrm{C}$. Then $15 \mathrm{ml}$ of methionine-free Dulbecco's modified Eagle's medium supplemented with $1 \%$ fetal bovine serum and $0.5 \mathrm{mCi}$ of ${ }^{35} \mathrm{~S}$ methionine ( $\mathrm{New}$ England Nuclear product NEG009T, USA) was added to the culture. The culture was allowed to incubate for 16 to $48 \mathrm{~h}$ to increase the amount of labeled viral proteins present in cells. The culture monolayer was rinsed once with plain DMEM (Dulbecco's modified Eagle's medium) to remove excess radiolabel and pelleted at $200 \times g$ in a Beckman GPR centrifuge. The pellet was sonicated at $4^{\circ} \mathrm{C}$ in 2 to $3 \mathrm{ml}$ of lysis buffer $(0.876 \mathrm{~g} \mathrm{NaCl}, 1.17 \mathrm{~g}$ sodium EDTA, $0.48 \mathrm{~g}$ Tris, $0.5 \mathrm{ml}$ NonIdet $\mathrm{P} 40$ in $100 \mathrm{ml}$ distilled water; $\mathrm{pH} 7.0$ ) for three $5 \mathrm{~s}$ pulses, followed by centrifugation at $134000 \times \mathrm{g}$ for $30 \mathrm{~min}$.

Immunoprecipitation of viral proteins. Immunoprecipitation of viral proteins was carried out by washing and centrifuging fixed Staphylococcus aureus cells (Calbiochem, USA, product \#07861) 3 times in immune precipitation buffer (IPT) $10.1 \%$ sodium dodecyl sulfate, $0.5 \%$ Nonidet P-40, $0.2 \%$ deoxycholate, $10 \mathrm{mM}$ Tris, $0.15 \mathrm{M}$ sodium chloride, $\mathrm{pH}$ 8) to remove fines. The final pellet was resuspended to $10 \%$ solids in IPT. For each sample, $100 \mu \mathrm{l}$ of staphylococcal protein A was dispensed into a $12 \times 75 \mathrm{~mm}$ tube. To immunoprecipitate the labeled nucleoprotein, $200 \mu \mathrm{l}$ of a pool of monoclonal antibodies (consisting of $50 \mu \mathrm{l}$ each of hybridoma supernatant from the cultures of $2 \mathrm{NH} 105 \mathrm{~B}, 1 \mathrm{NCO} 27 \mathrm{G}, 1 \mathrm{NH} 163 \mathrm{E}$ and $1 \mathrm{NDW} 14 \mathrm{D})$ was added to the staphylococcal protein $\mathrm{A}$. Antibody mixtures were allowed to incubate at $4{ }^{\circ} \mathrm{C}$ for $16 \mathrm{~h}$. Pellets were washed 3 times with IPI and centrifuged before 
the addition of antigen. Between 100 and $500 \mu$ of antigen was added to the antibody-charged pellets and the mixtures allowed to incubate at $4{ }^{\circ} \mathrm{C}$ for $16 \mathrm{~h}$. Pellets were washed 3 times with IPT and were boiled in $75 \mu \mathrm{l}$ Laemmli sample buffer (Laemmli 1970). Supernatants containing antigen were recovered from the pellets after centrifugation.

Sodium dodecyl sulfate polyacrylamide gel electrophoresis (SDS PAGE). SDS PAGE was performed according to the methods of Laemmli (Laemmli 1970) with a $5 \%$ stacking gel and a $13 \%$ separating gel. Molecular weight standards $\left({ }^{14} \mathrm{C}\right.$ ) (Amersham Corporation, Chicago, IL, USA) were employed which included the following proteins: myosin, $200 \mathrm{kD}$; phosphorylase $\mathrm{B}, 92.5 / 100 \mathrm{kD}$; bovine serum albumin $69 \mathrm{kD}$; ovalbu$\min , 46 \mathrm{kD}$; carbonic anhydrase, $30 \mathrm{kD}$; and lysozyme $14.3 \mathrm{kD}$. Electrophoresis was performed at $10 \mathrm{~mA}$ until the bromophenol blue dye marker reached the bottom of the gel. The gel was fixed for $30 \mathrm{~min}$ in methanol: acetic acid: water 45:10:45, followed by immersion in Amplify (Amersham). The gel was dried for 2 h on program 3 of a Model 543 gel dryer (BioRad) The dried gel was exposed to Kodak XLO film for 3 to $5 \mathrm{~d}$ and developed. Calculations of molecular weight were performed using the molecular weight values supplied by the manufacturer. For calculation of nucleoprotein molecular weights, a least squares equation was generated using the molecular weights of the ${ }^{14} \mathrm{C}$ standards (Amersham): ovalbumin, $46 \mathrm{kD}$; carbonic anhydrase, $30 \mathrm{kD}$; and lysozyme, $14.3 \mathrm{kD}$.

Fluorescence analysis of isolates. Isolates of IHNV were analyzed by indirect fluorescence with monoclonal antibodies made to the nucleoproteins and glycoproteins of the strains mentioned above. In order to perform the immunofluorescence assay, CHSE 214 cells were plated on glass coverslips deposited in 24well tissue culture plates. Coverslips were then incubated with $0.2 \mathrm{ml}$ of IHNV isolate and adsorbed at room temperature for $1 \mathrm{~h}$. One ml of complete medium RPMI 1640 supplemented with $10 \%$ fetal bovine serum (FBS) was added and the cultures incubated for 20 to $24 \mathrm{~h}$ at $16{ }^{\circ} \mathrm{C}$. Coverslips were rinsed briefly in cold calciummagnesium-free phosphate-buffered saline (CMF), pH 7.4, and fixed in acetone at $4^{\circ} \mathrm{C}$.

Coverslips were incubated with several drops of a predetermined dilution of monoclonal antibody for 30 min at $37^{\circ} \mathrm{C}$. They were rinsed thoroughly with CMF and the appropriate dilution of fluorescein conjugated rabbit anti-mouse immunoglobulin added and incubated for an additional $30 \mathrm{~min}$. Coverslips were washed again and counterstained with $0.05 \%$ Evans blue for 1 min and viewed under epifluorescence. A positive result was scored as brilliant apple-green fluorescence on a red background. All fluorescence assays were performed in duplicate and were read by 2 individuals.
Neutralization assay. Dilutions of virus and undiluted supernatant from hybridoma cultures containing monoclonal antibody were mixed on a shaker for $3 \mathrm{~h}$ at $16^{\circ} \mathrm{C}$ EPC cells (Fijan et al. 1983) plated on 24-well tissue culture plates were the indicator cell line. Antibody virus $(0.1 \mathrm{ml})$ mixture was added to the monolayer and the cultures rocked for $1 \mathrm{~h}$ at room temperature. Samples were then overlayed with Methocel in Dulbecco's modified Eagle's medium (Burke \& Mulcahy 1980). Plates were monitored for cytopathic effects, stained, and the $\log _{10}$ neutralization index (difference in exponents of $\mathrm{TCID}_{50}$ titration with and without neutralizing monoclonal antibody) calculated (Rovozzo \& Burke 1973).

Competition between monoclonal antibodies. In order to ascertain whether anti-glycoprotein monoclonal antibodies mapped to the same site on the $G$ protein of whole virus, a modification of the methods of Bricker et al. (1987) was employed. One hundred $\mu \mathrm{g}$ of purified monoclonal antibody was iodinated with carrier-free sodium iodine ( $\mathrm{Na}^{125} \mathrm{I}$ ) (New England Nuclear product \# NEZ033A) in Iodogen-coated tubes according to the methods described by the manufacturer (Pierce, Rockford, Il, USA). Excess free ${ }^{125} \mathrm{I}$ was removed by passing the labeled antibody over a Sephadex G-100 column equilibrated in PBS. Briefly, $0.5 \mu \mathrm{g}$ of the virus was allowed to attach overnight in $0.2 \mathrm{M}$ sodium bicarbonate buffer, $\mathrm{pH} 9.6$, to each well of an Immulon I plate containing breakaway wells (Dynatech, Alexandria, VA, USA). Plates were rinsed 3 times with phosphate-buffered saline containing $0.05 \%$ Tween $20, \mathrm{pH}=7.4$ (PBST) to remove any unattached virus. Dilutions of an ${ }^{125}$ I labeled monoclonal antibody in PBS containing $5 \%$ bovine serum albumin were added to the plate in duplicate and incubated for $2 \mathrm{~h}$ in order to determine the saturating concentration. A standard curve of antibody binding in counts per minute versus dilution was constructed and the saturating concentration determined. The saturating concentration of antibody was mixed with $100 \mu \mathrm{g}$ of unlabeled competing antibody and the mixture added to wells of the virus-coated plate in a total volume of $200 \mu \mathrm{l}$. Each test was performed in duplicate and the entire assay performed twice. Incubation proceded for $2 \mathrm{~h}$, whereupon the plates were washed 3 times with PBST. The wells were broken apart and individual wells counted in a gamma spectrometer. Percent inhibition of binding of the iodinated monoclonal antibody was calculated as follows:

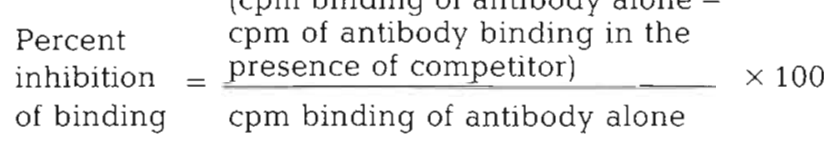

If inhibition of binding in this test takes place at greater than the $50 \%$ level, the antibodies are considered to bind at approximately the same site (Bricker et al. 1987). 


\section{RESULTS}

\section{Neutralization of 17 isolates by monoclonal antibodies}

All antibodies made to the glycoprotein of IHNV were tested for their ability to neutralize the virus. Within the group of antiglycoprotein antibodies, only 5 possessed neutralizing ability: 3GH127B, 3GH92A, 1GH131A, 3GH135L, and 2GH5F. The results of the neutralization tests by the 5 antibodies are presented in Table 2

Twelve of the 17 isolates were neutralized by both monoclonal antibodies $3 \mathrm{GH} 127 \mathrm{~B}$ and $3 \mathrm{GH} 92 \mathrm{~A}$. Five isolates not neutralized by the pair of antibodies were isolates from California and southern Oregon. ISSA. Coleman 1 (electropherotype III), Coleman 3 (electropherotype IV), Elk River (electropherotype III), Cole Rivers and the 1982 Rangen Research isolate from the Hagerman Valley (both electropherotypes undetermined). The only isolate among the group of 17 neutralized by antibody 1 GH131A was a 1983 Hagerman isolate, 039-82SR (Table 2). Neutralization indices of all isolates by antibodies $3 \mathrm{GH} 135 \mathrm{~L}$ and $2 \mathrm{GH} 5 \mathrm{~F}$ were not significant. Two isolates obtained from adult fish at Round Butte Hatchery in 1989, one from steelhead Oncorhynchus mykiss (OF32) and the other from chinook salmon $O$. tshawytscha (OF52), were neutralized equally well by $3 \mathrm{GH} 92 \mathrm{~A}$ and $3 \mathrm{GH} 127 \mathrm{~B}$.

The 2 antibodies, 3GH92A and 3GH127B, originally made by immunization of mice with the glycoprotein of the Hagerman isolate 039-82SR, mapped to approximately the same site on this isolate, as seen in Table 3 . Unlabeled 3GH92A was easily competed out by labeled 3GH127B. Likewise, unlabeled 3GH127B competed well with ${ }^{125} \mathrm{I}$ labeled $3 \mathrm{GH} 92 \mathrm{~A}$. Unlabeled $3 \mathrm{GH} 127 \mathrm{~B}$, however, did not efficiently inhibit ${ }^{125} \mathrm{I}$ labeled $3 \mathrm{GH} 127 \mathrm{~B}$. This result is difficult to reconcile but might be explained by the fact that $3 \mathrm{GH} 127 \mathrm{~B}$ is an

Table 3. Inhibition of ${ }^{125} \mathrm{I}$-labelled anti-glycoprotein antibodies with unlabelled antibodies to determine whether antibodies will bind to the same site on IHNV

\begin{tabular}{|lcccc|}
\hline $\begin{array}{c}\text { 125 I-labelled } \\
\text { antibody }\end{array}$ & 3GH92A & Competing antibodies \\
\hline 3GH127B & 1 GH131A & 3GH135L \\
\hline 3GH92A & $97 \%$ & $94 \%$ & $46 \%$ & $\begin{array}{r}35 \% \\
0 \%\end{array}$ \\
$3 \mathrm{GH} 127 \mathrm{~B}$ & $93 \%$ & $62 \%$ & $11 \%$ & 0 \\
\hline
\end{tabular}

IgM antibody and that iodination altered it to make it bind more efficiently than its unlabeled counterpart to the virus on the plate. Although the serum neutralization data in Table 2 combined with the results of Table 3 strongly suggest that $3 \mathrm{GH} 127 \mathrm{~B}$ and $3 \mathrm{GH} 92 \mathrm{~A}$ see approximately the same epitope on a number of isolates of IHNV, inspection of fluorescence data in Table 4 shows that although all 17 isolates are positive with $3 \mathrm{GH} 127 \mathrm{~B}$, only 12 were positive with 3GH92A, indicating that there may be a small difference in specificity between 3GH127B and 3GH92A.

\section{Fluorescence assays}

Results of indirect fluorescence assays using 27 monoclonal antibodies and 17 selected isolates of

Table 2. Tests of neutralization utilizing 5 anti-glycoprotein antibodies. Species abbreviations as in Table 1

\begin{tabular}{|c|c|c|c|c|c|c|c|}
\hline Isolate & Species & Year & $3 \mathrm{GH} 127 \mathrm{~B}$ & $3 \mathrm{GiH} 92 \mathrm{~A}$ & $1 \mathrm{GH} 131 \mathrm{~A}$ & 3GH135L & $2 \mathrm{GH} 5 \mathrm{~F}$ \\
\hline Cedar River & SS & 1980 & 3.2 & 3.7 & - & 0.4 & - \\
\hline Cedar River & SS & 1989 & 3.1 & 3.8 & - & 0.6 & - \\
\hline Coleman 1 & $\mathrm{Ch}$ & 1982 & - & - & - & - & - \\
\hline Coleman 3 & $\mathrm{Ch}$ & 1979 & - & - & - & - & - \\
\hline Cole Rivers & $\mathrm{Ch}$ & 1989 & - & - & - & 0.6 & 0.1 \\
\hline Dworshak & St & 1982 & 3.4 & 4.4 & - & 0.6 & 0.5 \\
\hline Dworshak & St & 1989 & 3.5 & 3.9 & - & 0.5 & - \\
\hline Elk River & $\mathrm{Ch}$ & 1982 & - & - & - & 0.5 & - \\
\hline Hagerman $039-82$ SR & $\mathrm{RbT}$ & 1982 & 2.7 & 3.4 & 2.6 & 0.3 & - \\
\hline Hagerman $039-82$ oSU & $\mathrm{RbT}$ & 1982 & 1.9 & 2.7 & - & - & - \\
\hline Little White Salmon & $\mathrm{Ch}$ & 1987 & 2.9 & 4.5 & - & - & - \\
\hline Metolius & $\mathrm{KO}$ & 1988 & 3.3 & 3.3 & - & 0.1 & - \\
\hline Rangen Research & $\mathrm{RbT}$ & 1983 & - & - & - & 0.1 & - \\
\hline Round Butte & St & 1983 & 4.2 & 4.5 & - & 0.5 & - \\
\hline Round Butte & St & 1986 & 3.2 & 3.8 & - & 0.6 & - \\
\hline Round Butte & St & 1989 & 3.7 & 4.3 & - & 0.3 & - \\
\hline Round Butte & Ch & 1989 & 3.0 & 3.2 & - & - & - \\
\hline
\end{tabular}




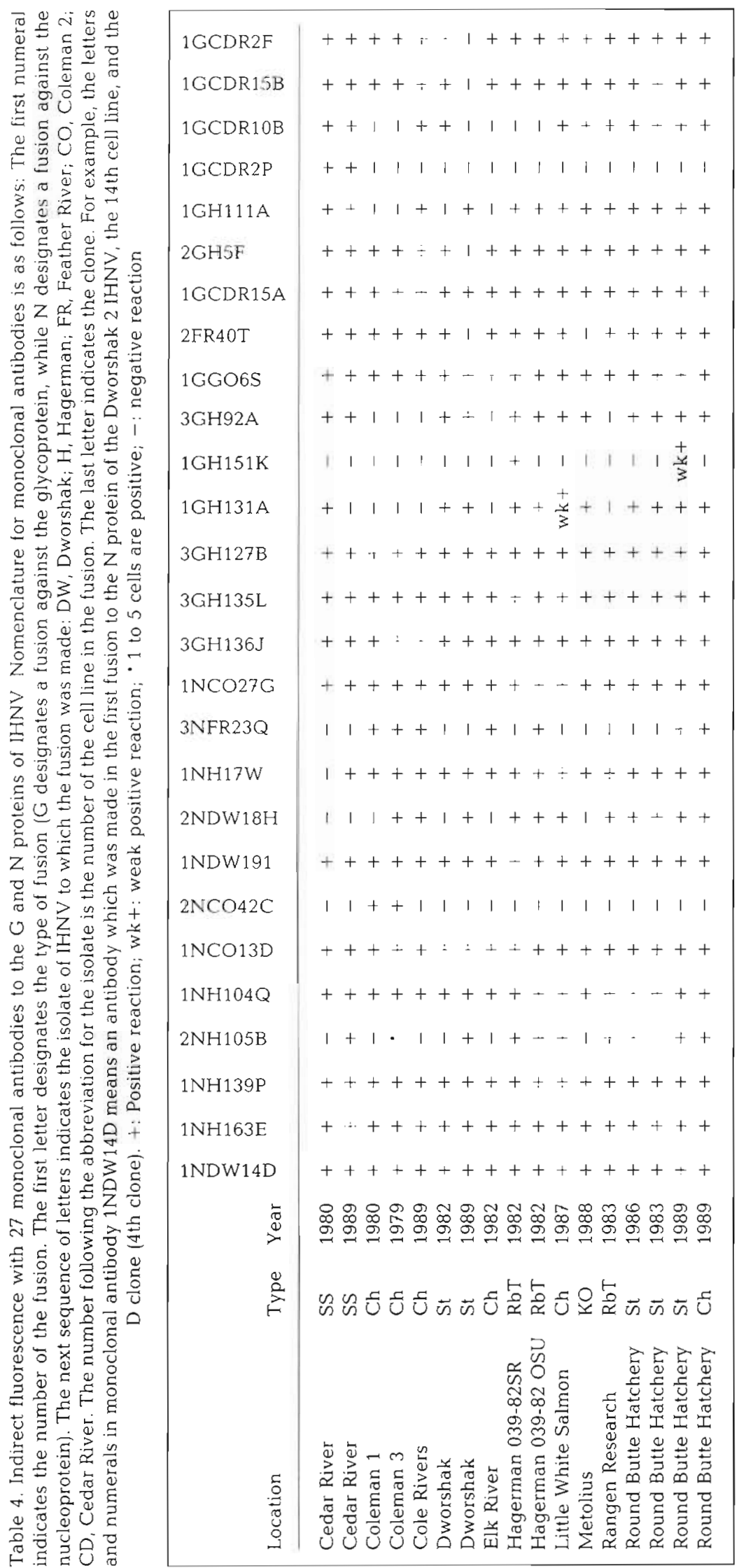


IHNV appear in Table 4. All of the isolates gave positive reactions with the antinucleoprotein antibodies, 1NDW14D (first column) and 1NH139P (third column), both of which have identified more than 150 isolates of IHNV in our laboratory. With the anti-nucleoprotein monoclonal 2NH105B, which identifies mainly electrophoretic type 2 IHNV (Ristow \& Arnzen 1989), there were 9 positive reactions given by the following isolates: Cedar River 1989, Dworshak 1989, Hagerman 039-82OSU, Hagerman 039-82SR, Little White Salmon, Rangen Research, and 3 Round Butte Hatchery isolates. The earliest isolate from Round Butte in 1982 was negative with $2 \mathrm{NH} 105 \mathrm{~B}$, whereas the most recent 3 isolates dated 1986 and 1989 were positive. With the Coleman 3 isolate, results were equivocal with 2NH105B, with 1 to 5 cells being positive per coverslip. This result indicates that this may be a mixed isolate.

Only 2 of the 17 isolates were positive with $2 \mathrm{NCO} 42 \mathrm{C}$, an antibody originally made to the nucleoprotein of Coleman 2, an electrophoretic type 4 IHNV (Hsu et al. 1986). Likewise, anti-glycoprotein antibody $1 \mathrm{GH} 151 \mathrm{~K}$ was positive with only 2 isolates, the Hagerman isolate 039-82SR and the 1989 steelhead isolate from Round Butte. The two 1982 Hagerman 039-82 isolates from rainbow trout differ by reaction with 2 antibodies, 1GH151K and 3NFR23Q, as well as by neutralization with antibody 1 GH131A (Table 2).

All 17 isolates, with the exception of Cedar River 1980, were positive with $1 \mathrm{NH} 17 \mathrm{~W}$, which distinguished between the nucleoproteins of isolates within the same electropherotype (See Table 5 which contains the results of tests of indirect fluorescence on selected isolates electropherotyped by $\mathrm{Hsu}$ et al. 1986). With antibody $2 \mathrm{NDW} 18 \mathrm{H}$, made to the nucleoprotein of the DW2 Dworshak isolate (Hsu et al. 1986), 11 of the 17 isolates were positive. Like $1 \mathrm{NH} 17 \mathrm{~W}, 2 \mathrm{NDW} 18 \mathrm{H}$ also distinguished between nucleoproteins of isolates having the same electrophoretic type (Table 5).

Twelve of the 27 monoclonal antibodies were positive by indirect fluorescence on all 17 of the isolates in Table 4. Anti-nucleoprotein antibodies which reacted with all of the 17 isolates were: 1NDW14D, 1NH163E, 1NH139P, 1NH104Q, 1NCO13D, 1NDW19I, and $1 \mathrm{NCO} 27 \mathrm{G}$. Likewise, the anti-glycoprotein antibodies which reacted with all 17 isolates were: 3GH136J, 3GH135L, 3GH127B, 1GCO6S and 1GCDR15A.

Although $3 \mathrm{GH} 127 \mathrm{~B}$ stained all 17 isolates in indirect fluorescence, it did not neutralize all of the isolates in the plaque neutralization studies. With respect to the fluorescence tests and reaction with the antiglycoprotein antibodies, the Coleman 1, Coleman 3 and Elk River, all California/southern Oregon chinook salmon (Oncorhynchus tshawytscha) isolates have the same glycoprotein fluorescence reaction pattern, although the reactions of their nucleoproteins differ. The 1989
Cole Rivers chinook isolate glycoprotein differs from the glycoproteins of the California Coleman isolates by a positive reaction with the 1 GCDR10B antibody. The 2 Cedar River sockeye salmon ( $O$. nerka) isolates are unique because they are the only isolates in the group of 17 which reacted with 1 GCDR2P, an antibody made to the glycoprotein of the 1980 Cedar River isolate from sockeye

Both the two 1989 Round Butte Hatchery isolates, one from chinook and the other from steelhead, had the same fluorescence patterns with the panel of monoclonal antibodies, with the exception that the steelhead isolate was weakly positive with $1 \mathrm{GH} 151 \mathrm{~K}$. The 1983 , 1986 and 1989 Round Butte steelhead isolates are similar with respect to most of the epitopes defined by the monoclonal antibodies. The 1983 isolate, however, was negative with $2 \mathrm{NH} 105 \mathrm{~B}$, indicating that it probably was not a Type II virus (Hsu et al. 1986, Ristow \& Arnzen 1989). In addition, both older Round Butte isolates were negative with 3NFR23Q, while the 1989 isolates were positive.

Inspection of the results presented in Table 5, which includes many of the older isolates of IHNV, indicates that wide antigenic variation existed in the nucleproteins and glycoproteins of the isolates representing different electropherotypes classified by $\mathrm{Hsu}$ et al. (1986). It was noted that 2 of the viruses categorized as electrophoretic Type I, Nimpkish and Dworshak 2, were positive with the $2 \mathrm{NH} 105 \mathrm{~B}$ antibody. In addition, Cowlitz 7 and Elk River, previously classified as electrophoretic Type II and Type III viruses, respectively, were positive with $2 \mathrm{NCO} 42 \mathrm{C}$, an antibody which was originally raised to Coleman 2 IHNV (a Type IV virus). Anti-nucleoprotein antibodies 1NH17W, 1NDW19I, and $2 \mathrm{NDW} 18 \mathrm{H}$ revealed differences between isolates within particular electrophoretic classifications. Likewise, antiglycoprotein antibodies 3GH127B, 1GH131A, 1GH111A, 3GH92A, 1GH151K, 1GCDR2F, and 1 GCDR15B showed the heterogeneity of glycoproteins within each category.

Similar heterogeneity among 1989 and 1990 isolates of IHNV was seen by fluorescent antibody staining (Table 6). Sampling within lots of fish from a single hatchery revealed heterogeneity in both the glycoproteins and nucleoproteins of the virus (see Hagerman lots 36 through 39 from 1990). All recent isolates listed in Table 6 were positive for $2 \mathrm{NH} 105 \mathrm{~B}$, with the exception of the 1989 Coleman isolate and the 1990 Coleman isolate which gave equivocal results with 1 to 5 cells being positive per coverslip. Most isolates from the Columbia basin were negative with $2 \mathrm{NCO} 42 \mathrm{C}$ with the exception of Hagerman lot \#39 and Little White Salmon (on the Columbia River) which gave equivocal reactions. The 2 Coleman isolates from California, 1989 and 1990, were positive with this antibody 


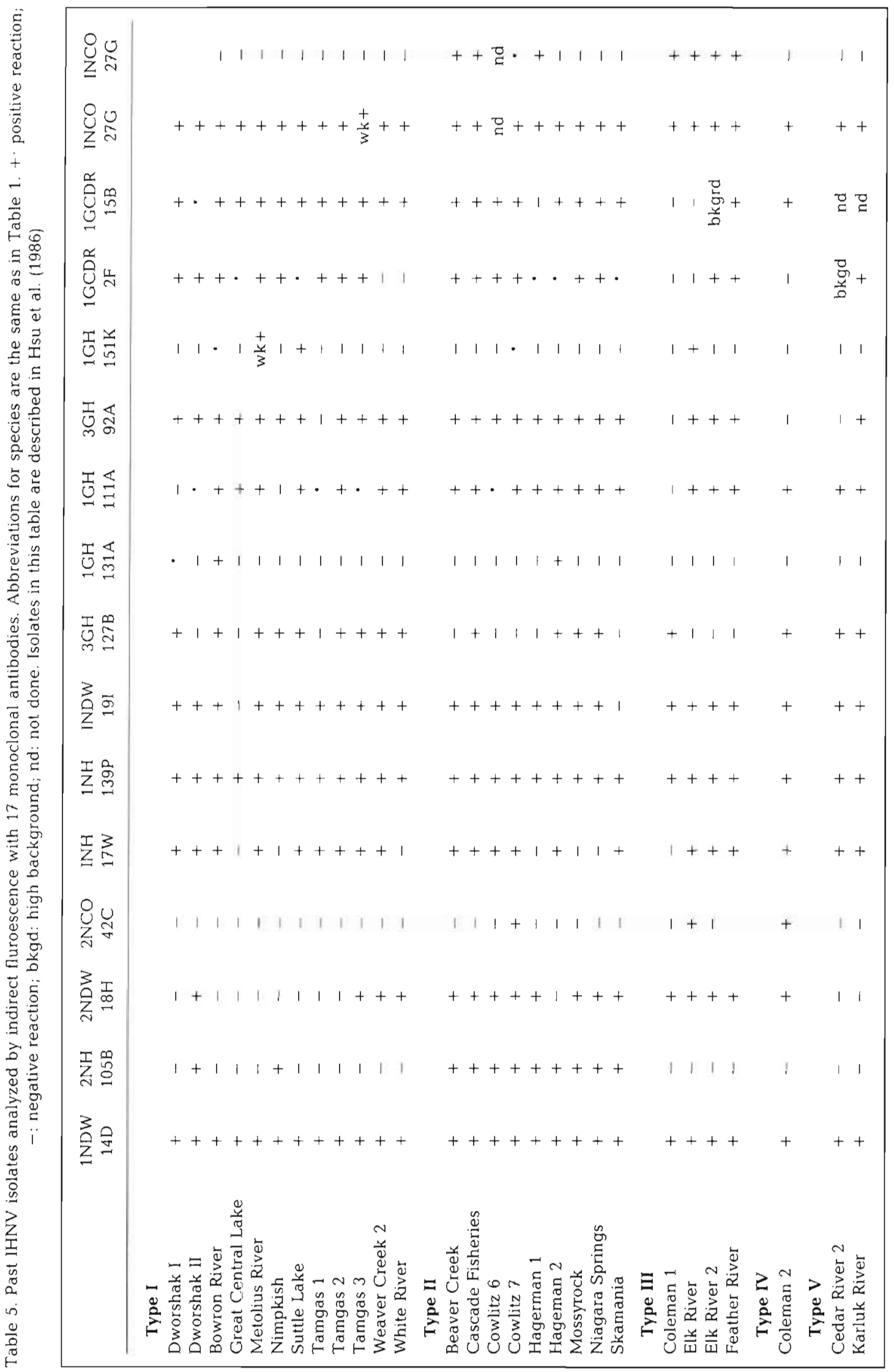


Table 6. Results of indirect fluorescence tests on recent isolates using selected anti-IHNV monoclonal antibodies. Abbreviations for species as in Table 1. +: positive reaction; - : negative reaction; wkt: weak positive reaction

\begin{tabular}{|c|c|c|c|c|c|c|c|c|c|c|c|c|}
\hline Location & Species & Yeat & $\begin{array}{l}1 \mathrm{GH} \\
131 \mathrm{~A}\end{array}$ & $\begin{array}{l}3 \mathrm{GH} \\
92 \mathrm{~A}\end{array}$ & $\begin{array}{l}1 \mathrm{GH} \\
111 \mathrm{~A}\end{array}$ & $\begin{array}{l}3 \mathrm{GH} \\
127 \mathrm{~B}\end{array}$ & $\begin{array}{c}2 \mathrm{GH} \\
2 \mathrm{~F}\end{array}$ & $\begin{array}{c}2 \mathrm{GH} \\
5 \mathrm{~F}\end{array}$ & $\begin{array}{l}2 \mathrm{NH} \\
105 \mathrm{~B}\end{array}$ & $\begin{array}{c}2 \mathrm{NCO} \\
42 \mathrm{C}\end{array}$ & $\begin{array}{l}1 \mathrm{NH} \\
17 \mathrm{~W}\end{array}$ & $\begin{array}{c}\text { 2NDW } \\
18 \mathrm{H}\end{array}$ \\
\hline Dworshak OF \# $\# 70$ & St & 1990 & - & + & + & + & - & + & + & - & -- & + \\
\hline Hagerman Lot \#36 & St & 1990 & - & - & + & + & + & $w k+$ & + & - & + & + \\
\hline Hagerman Lot \#37 & St & 1990 & - & - & + & + & + & + & + & - & + & + \\
\hline Hagerman Lot \#38 & $\mathrm{St}$ & 1990 & - & - & + & - & - & - . & + & - & - & + \\
\hline Hagerman Lot $\# 39$ & St & 1990 & - & - & + & + & + & + & + & wk+ & + & + \\
\hline Lyons Ferry & $R b T$ & 1989 & - & + & + & + & + & + & + & - & + & + \\
\hline Warm Springs & $\mathrm{RbT}$ & 1989 & - & + & $w k+$ & + & + & + & + & - & + & + \\
\hline Little White Salmon & $\mathrm{Ch}$ & 1989 & - & + & + & + & + & + & + & $w k+$ & + & + \\
\hline Coleman & $\mathrm{Ch}$ & 1989 & + & - & + & + & + & $\frac{1}{3}$ & - & + & + & + \\
\hline Coleman & $\mathrm{Ch}$ & 1990 & + & - & $w k+$ & + & + & + & $w k+$ & + & + & + \\
\hline
\end{tabular}

\section{Molecular weight typing of viral nucleoprotein polypeptides}

Photographs of the autoradiograms of the nucleoprotein immunoprecipitations by the monoclonal antibody mixture (2NH105B, 1NCO27G, 1NH163E AND 1NDW14D) are presented in Figs. 1 \& 2. Nucleoprotein molecular weight values are given in Table 7 . The calculation of nucleoprotein molecular weights was made on the basis of electrophoresis on both $10 \%$ and $13 \%$ resolving gels. Ten percent gels revealed only small differences among nucleoprotein molecular weights (data not shown). The range of values obtained for the series of nucleoproteins on $13 \%$ gels was 41.2 to $42.4 \mathrm{kD}$. The Elk River isolate had the nucleoprotein of greatest relative mobility, while the nucleoproteins of the other isolates varied from one another by only tenths of a kiloDalton ( $\mathrm{kD})$.

\section{DISCUSSION}

The data presented above indicate that a number of different forms of IHNV (as judged by polypeptide analysis on SDS-PAGE, serum neutralization, and fluorescence analysis) have existed inside and outside the Columbia Basin within the past decade. In several respects, our results by neutralization, SDS PAGE and fluorescence analysis agree with Hsu et al. (1986); e.g. the observation that 2 different species of fish (chinook salmon and steelhead) in the same hatchery (e.g. isolates from Round Butte Hatchery, 1989) may be infected with the same virus. The fluorescence and neutralization analyses, however, revealed that different forms of IHNV could also exist within a particular geographic area in the same year (e.g. the 2 Hagerman 1982 isolates).

Electropherotyping of IHNV by Hsu et al. (1986) and
Fig. 1. Nucleoproteins precipitated by monoclonal antibody mixture and electrophoresed on a $13 \%$ gel. Order of electrophoresis: Lane $1,{ }^{14} \mathrm{C}$ standard; Lane 2, Cedar River 1980; Lane 3. Cedar River 1989; Lane 4, Cole Rivers; Lane 5, Coleman 1; Lane 6 . Coleman 3; Lane $7,{ }^{14} \mathrm{C}$ standard; Lane 8, Dworshak 1980; Lane 9. Dworshak 1989, Lane 10, Elk River. Photo is a 3 d exposure of Kodak XLO film to the gel 
Fig. 2. Nucleoproteins precipitated by monoclonal antibody mixture and electrophoresed on a $13 \%$ gel. Lane 1. Hagerman 03982 SR; Lane 2, Hagerman 03982 OSU; Lane 3, Little White Salmon; Lane 4, Metolius; Lane 5, Rangen Researchi Lane $6,{ }^{14} \mathrm{C}$ standards; Lane 7, Round Butte Hatchery 1983; Lane 8, Round Butte Hatchery, 1986; Lane 9, Round Butte Hatchery (Steelhead Isolate), 1989; Lane 10, Round Butte Hatchery (Chinook Isolate), 1989. Photo is a $3 \mathrm{~d}$ exposure of Kodak XLO film to the gel

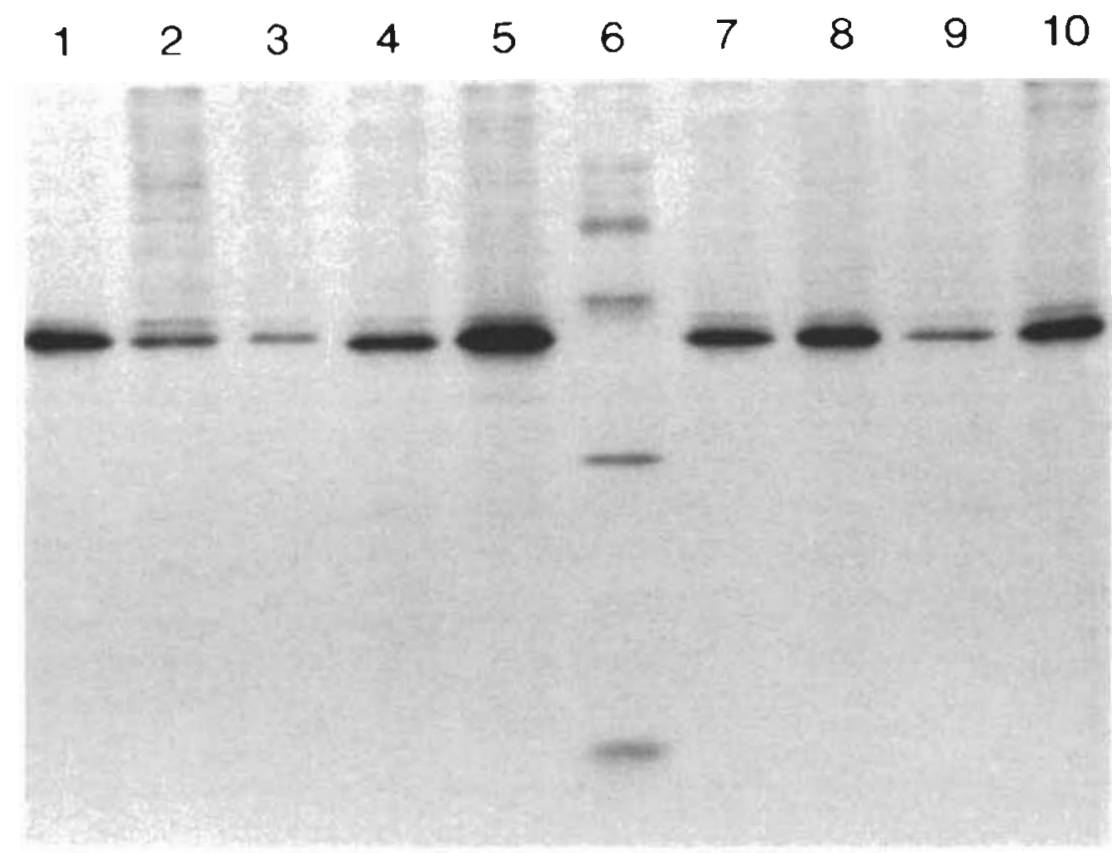

other investigators has shown that Type I virus previously predominated in Canada and in the USA (Washington, Oregon) while Type II virus appeared further inland and is now endemic in trout Oncorhynchus mykiss in southern Idaho. Types III and IV virus are forms of IHNV which have predominated in chinook salmon $O$. tshawytscha in Oregon and California, USA. The ability of SDS-PAGE electropherotyping to distinguish between strains of IHNV primarily rests with the determination of the molecular weight of the nucleoprotein (Hsu et al. 1986).

Table 7. Molecular weights of the nucleoproteins of 17 isolates of IHNV as determined by SDS-PAGE. Abbreviations for species as in Table 1

\begin{tabular}{|c|c|c|c|}
\hline Location & Year & Species & Mol. wt \\
\hline Cedar River & 1980 & SS & 41.3 \\
\hline Cedar River & 1989 & SS & 41.0 \\
\hline Coleman 1 & 1982 & $\mathrm{Ch}$ & 41.7 \\
\hline Coleman 3 & 1979 & $\mathrm{Ch}$ & 41.5 \\
\hline Cole Rivers & 1989 & $\mathrm{Ch}$ & 41.2 \\
\hline Dworshak & 1982 & St & 42.0 \\
\hline Dworshak & 1989 & St & 41.8 \\
\hline Elk River & 1982 & $\mathrm{Ch}$ & 42.4 \\
\hline Hagerman 039-82SR & 1982 & $\mathrm{RbT}$ & 41.7 \\
\hline Hagerman 039-82OSU & 1982 & $\mathrm{RbT}$ & 41.5 \\
\hline Littel White Salmon & 1987 & $\mathrm{Ch}$ & 41.3 \\
\hline Metolius & 1989 & $\mathrm{KO}$ & 41.4 \\
\hline Rangen Research & 1983 & $\mathrm{RbT}$ & 41.5 \\
\hline Round Butte Hatchery & 1983 & St & 41.2 \\
\hline Round Butte Hatchery & 1986 & St & 41.5 \\
\hline Round Butte Hatchery (OF32) & 1989 & St & 41.5 \\
\hline Round Butte Hatchery (OF52) & 1989 & $\mathrm{Ch}$ & 41.5 \\
\hline
\end{tabular}

When both $10 \%$ and $13 \%$ polyacrylamide separating gels were tested for the ability to distinguish between the isolates, the $13 \%$ gel revealed fine differences in molecular weight among the nucleoproteins. The SDS-PAGE method of typing virus, although it yields approximate molecular weight values for each isolate, is subject to a number of errors, including estimates of relative mobility ( $r_{f}$ values) for each of the polypeptides, and errors introduced by drying the gel onto a fixed support. In our hands, the isolates could not be strictly classified into electrophoretic types as described by Hsu et al. (1986).

The molecular weights of the glycoproteins of most strains of IHNV have been found to be relatively constant at $67 \mathrm{kD}$, with the exception of those isolates classified as Type IV, whose $G$ protein molecular weight is $70 \mathrm{kD}$ (Hsu et al. 1986). The molecular weight calculation for the IHNV G protein is also subject to error depending on the amount of protein loaded onto the gel and on the extent of glycosylation of the glycoproteins. On SDS PAGE, glycoproteins produce wide bands, the center of which is sometimes difficult to estimate. Electrophoresis was performed on immunoprecipitates of the $G$ proteins of the 17 isolates, with negligible differences noted among $G$ molecular weights (data not shown).

Unlike electropherotyping, fluorescence analysis of an isolate is fast, economical, and requires no radioactive material. After infection of CHSE-214 cells, staining can be completed and the coverslips read within a $2 \mathrm{~h}$ period. It is convenient to determine whether an isolate contains the epitope associated with IHNV Type II by staining a coverslip with $2 \mathrm{NH} 105 \mathrm{~B}$ (Ristow \& 
Arnzen 1989). The utility of the monoclonal library for fluorescence analysis of some recent isolates is evident from the data presented in Tables 4 \& 5 .

We have found, as have Winton et al. (1988), that neutralization of isolates with anti-glycoprotein antibodies is a very valuable tool. This method is able to identify differences in the neutralizing epitopes in the glycoprotein coat of the virus. Clearly, the California/ southern Oregon isolates (Cole Rivers, Elk River and the 2 Coleman isolates) are different from the majority of the isolates from the Columbia Basin, with the exception of the Rangen Research isolate which was originally obtained from an epizootic associated with mortality among larger trout (LaPatra et al. 1990). Although several anti-glycoprotein antibodies in our collection were reactive with isolates by fluorescence assay, the same antibodies were not able to neutralize the isolates, indicating that there are fine differences in fit of epitopes and antibodies between isolates, and that positivity in the fluorescence test by a monoclonal antibody does not guarantee neutralization by that antibody.

We did not consider it unusual to have found the many differences in epitopes among the IHNV isolates which we studied. The high mutation rate of RNA viruses is now well documented (reviewed by Holland et al. 1982, Steinhauer \& Holland 1987) and has been attributed to the lack of proofreading enzymes in RNA replicases. The prototype rhabdovirus, vesicular stomatitis virus (VSV), has exhibited wide antigenic variation in the glycoprotein as well as in other virus structural proteins (Nichol 1987, Nichol et al. 1989, Bilsel \& Nichol 1990, Luo et al. 1990). From an analysis of the glycoprotein gene sequences of VSV-Indiana, it is possible to deduce lineages or subtypes within groups of isolates of this serotype of VSV, and it is further speculated that immune selection plays a role in the overall evolution of VSV (Bilsel \& Nichol 1990). It is entirely probable that an analogous evolutionary process is occurring with IHNV. In the future, it will be important to sequence the genomes of a number of IHNV isolates to deduce which genomic mutations have produced the antigenic differences defined by the monoclonal antibodies described in this paper and to determine whether any of the epitopes identified by the monoclonal antibodies correlate with virulence for particular species of salmonids.

Acknowledgements. We owe our thanks to the many researchers and hatchery personnel who helped us gather virus isolates to complete this work. We thank Donna Schiffner and Chris Smith for competent technical assistance. This work was supported by the Bonneville Power Administration program DE-PS79-88BP92431, USDA grant 87-CRSR-2-3039, by the Washington Technology Center and by grants 87 -CRSR-2$3219,88-38500-4027$ and 89-38500-4287 from the USDA to the
Western Regional Aquaculture Consortium. This is scientific paper no. 8045 from the College of Agriculture and Home Economics Research Center, Washington State University.

\section{LITERATURE CITED}

Arkush, K. D., Bovo, G., de Kinkelin, P., Winton J. R., Wingfield, W. H., Hedrick, R. P. (1989). Biochemical and antigenic properties of the first isolates of infectious hematopoietic necrosis virus from salmonid fish in Europe. J. aquat. Anim. Health 1:148-153

Bilsel, P. A., Nichol, S. T. (1990). Polymerase errors accumulating during natural evolution of the glycoprotein gene of vesicular stomtitis virus Indiana serotype isolates. J. Virol. 64: $4873-4883$

Bricker, B. J., Snyder, R. M., Fox, J. A., Volk, W. A., Wagner, R. R. (1987). Monoclonal antibodies to the glycoprotein of vesicular stomatitis virus (New Jersey serotype): a method for preliminary mapping of epitopes. Virol, 161: 533-540

Burke, J. A., Mulcahy, D. (1980). Plaquing procedure for infectious hematopoietic necrosis virus. Appl. environ. Microbiol. 39: 872-876

Fijan, N., Salimanovic, D., Bearzotti, M., Muzinić, D., Zwillenberg, L. O., Chilmonczyk, S., Vautherot, J. F., de Kinkelin, P. (1983). Some properties of the Epithelioma Papulosum Cyprini (EPC) cell line from Carp Cyprinus carpio Ann. Virol. (Inst. Pasteur) 134E: 207-220

Fryer, J. L. (1985). Epidemiology and control of infectious diseases of salmonids in the Columbia River basin. Bonneville Power Administration, Annual Report Fiscal Year 1984, Project 83-312, Bonneville Power Administration, Portland, Oregon

Groberg, W J., Fryer J. L. (1983). Increased occurences of infectious hematopoietic necrosis virus in fish at Columbia river basin hatcheries: 1980-1982. Oregon State University Sea Grant College Program, OREOSU-T-83-002, Corvallis

Hattenberger-Baudouy, A. M., Danton, M., Merle, G., Torchy, C., de Kinkelin, P. (1989). Serological evidence of infectious hematopoietic necrosis in rainbow trout from a French outbreak of the disease. J. aquat. Anim. Health 1:126-134

Holland, J., Spindler, K., Horodyski, F., Grabau, E., Nichol, S., VandePol, S. (1982). Rapid evolution of RNA genomes. Science 215: 1577-1585

Hsu, Y.-L., Engelking, H. M., Leong, J. C. (1986). Occurrence of different types of infectious hematopoietic necrosis virus in fish. Appl environ. Microbiol. 52: 1353-1361

Kurath, G., Ahern, K. G., Pearson, G. D., Leong, J. C. (1985). Molecular cloning of the six mRNA species of infectious hematopoietic necrosis virus, a fish rhabdovirus, and gene order determination by R-loop mapping. J. Virol. 53: $469-476$

Kurath G., Leong J. C. (1985) Characterization of infectious hematopoietic necrosis virus mRNA species reveals a nonvirion rhabdovirus protein. J. Virol. 53: 469-476

Laemmli, U. K. (1970). Cleavage of structural proteins during the assembly of the head of bacteriophage T4. Nature (Lond.) 227: 680-685

LaPatra S. E., Groberg W. J., Rohovec J. S., Fryer J. L. (1990) Size-related susceptibility of salmonids to two strains of infectious hematopoietic necrosis virus. Trans. Am. Fish. Soc. 119: $25-30$

Luo, L., Snyder, R. M., Wagner, R. R. (1990). Spontaneous mutations leading to antigenic variations in the glycoproteins of vesicular stomatitis field isolates. Virol. 174:70-78 
Luqi, N., Zhizhuang, Z. (1988). The epidemiology of IHN and IPN of rainbow trout in Northeast China. J. Fish. China 12: 327-332

McAllister, P. E., Wagner, R. R. (1975). Structural proteins of two salmonid rhabdoviruses. J. Virol. 15: 733-738

McCain, B. B., Fryer, J. L., Pilcher, K. S. (1971). Antigenic relationships in a group of three viruses of salmonid fish by cross neutralization. Proc. Soc. exp. Biol. Med. 137: 1042-1046

Nichol, S. T. (1987). Molecular epizootiology and evolution of vesicular stomatitis virus New Jersey. J. Virol. 61. 1029-1036

Nichol, S. T., Rowe, J. E., Fitch, W. M. (1989). Glycoprotein evolution of vesicular stomatitis New Jersey. Virol. 168: 281-291

Nims, L., Fryer, J. L., Pilcher, K. (1970). Studies on replication of four selected viruses in two cell lines derived from salmonid fish. Proc. Soc. Exp. Biol. Med. 135:6-12

Pilcher, K. S., Fryer, J. L. (1980). The viral diseases of fish: a

Responsible Subject Editor: W. Ahne, Munich, Germany review through 1978. Part 1: diseases of proven viral etiology. Crit. Rev. Microbiol. 7: 287-363

Ristow, S. S., Arnzen, J. M. (1989). Development of monoclonal antibodies that recognize a Type 2 specific and a common epitope on the nucleoprotein of infectious hematopoietic necrosis virus. J. aquat. Anim. Health 1: $119-125$

Rovozzo, G. C., Burke, C. N. (1973). A manual of basic virological techniques. Prentice-Hall, Englewood Cliffs

Sano, T. (1976). Viral diseases of cultured fishes in Japan. Fish Pathol. 10: 221-226

Steinhauer, D. A., Holland, J. J. (1987). Rapid evolution of RNA viruses. Ann. Rev. Microbiol. 41: 409-433

Winton, J. R., Arakawa, C. K., Lannan, C. N., Fryer, J. L. (1988). Neutralizing monoclonal antibodies recognize antigenic variants among isolates of infectious hematopoietic necrosis virus. Dis. aquat. Org. 4: 199-204

Wolf, K. (1988). Fish viruses and fish viral diseases, 1 st edn. Cornell University Press, New York

Manuscript first received: December 13, 1990

Revised version accepted: April 19, 1991 